\title{
EARLY DIAGNOSIS OF ARTHRITIS OF THE HAND CLINICOPATHOLOGICAL STUDY OF SWOLLEN PAINFUL HANDS IN WOMEN OVER 40 YEARS OF AGE
}

\author{
BY \\ E. A. KAUFFMANN* AND R. FINLAYSON $\dagger$ \\ From the Royal Free Hospital, London
}

Swollen and painful joints in the hands of women over 40 years of age present a diagnostic problem. We have seen a number of patients whose signs and symptoms conformed to the criteria laid down by Kellgren and Moore (1952) for primary generalized osteo-arthritis but who, in addition, had swollen and painful metacarpophalangeal joints, particularly the second and third, and often involvement of the wrists. Frequently there was associated periarticular swelling.

In these cases the differential diagnosis between osteo-arthritis and rheumatoid arthritis on clinical, radiological, or serological grounds was extremely difficult.

The purpose of the present investigation was to determine to what extent biopsy of the small joints of the hand could contribute to an earlier diagnosis. Histological studies of joint tissue in rheumatoid arthritis and osteo-arthritis have mostly been confined to biopsy specimens from large joints or post mortem material. Early joint lesions in rheumatoid arthritis were described by Kulka, Bocking, Ropes, and Bauer (1955), using biopsy material from the knee joint. Cruickshank (1952), discussing changes in the synovial tissue in rheumatoid diseases, included the proximal interphalangeal joint, but we have been unable to find any reference to a series of biopsy studies of the small joints of the hand.

The present study was therefore concerned with three main problems:

(1) To find out whether biopsy of a small joint of the hand was a reasonable operative procedure, yielding sufficient suitable material.

(2) To find out whether the histological picture of the biopsy material could be correlated

\footnotetext{
* Present address: Arthur Stanley Institute, Middlesex Hospital, London.

+ Present address: St. Bartholomew's Hospital, London.
}

with the clinical picture of the patient at the time of biopsy or on follow-up.

(3) To assess the place of biopsy in the diagnosis of doubtful cases of arthritis of the hands.

\section{Material}

Thirty women who complained of pain and swelling of the hands with involvement of the second metacarpophalangeal joint were subjected to biopsy of this joint (Table, overleaf, pp. 234 and 235).

Three of these patients, all aged 38 to 39 years, had typical early rheumatoid arthritis (Cases 1-3). Symptoms had been present for less than 6 months, and the Rose-Waaler test was positive within 3 months of biopsy.

They showed no radiological evidence of osteoarthritis.

Three other patients aged 48 to 55 years, had uncomplicated generalized osteo-arthritis (Cases 22, 23 and 29).

In the remaining 24 patients, whose ages ranged from 40 to 75 years, certain features of both diseases were present. All had clinical evidence of osteo-arthritis, such as Heberden's nodes or thumb-base arthritis, together with radiographic evidence of degenerative joint changes. Constitutional symptoms were not marked and the erythrocyte sedimentation rate was not greatly raised.

In seven of these 24 patients (Cases 4 to 10), aged 42 to 71 years, a presumptive diagnosis of rheumatoid arthritis was made at the time of biopsy on the basis of the history and clinical findings alone in Cases 6 and 10, with the added evidence of the positive Rose-Waaler test in Cases 4, 8, and 9, and of joint erosions revealed by $x$-ray examination in Cases 4,5 , and 7 .

In two other patients (Cases 25 and 27), a tentative diagnosis of osteo-arthritis was made.

In the remaining fifteen cases no diagnosis could be made at the time of biopsy.

\section{Methods}

Since needle biopsy of the second metacarpophalangeal joint had proved unsatisfactory an open approach was 
used. Biopsies were taken both under local and general anaesthesia. The second metacarpophalangeal joint was exposed from the dorso-medial aspect by incision of the skin and longitudinal splitting of the extensor tendon and joint capsule. A small piece of joint tissue and capsule was removed and the wound closed with interrupted sutures. No complications followed this procedure. Initially a dorso-lateral approach to the joint was employed, but this was abandoned because the extensor tendon could not be adequately secured and was liable to slip across the knuckle.

After fixation in 10 per cent. formol saline, the biopsy tissue was secondarily fixed in formol-sublimate before dehydration, clearing, and paraffin embedding. Haematoxylin and eosin stained sections were examined; additional stains used included Mallory's phosphotungstic acid haematoxylin, Orcein-Van Gieson's stain, a modified picro-Mallory technique, a modified Wilder's silver impregnation method for reticulin fibres, Azure A for mast cells, Trevan and Sharrock's method for plasma cells, and Perls' Prussian blue reaction for haemosiderin.

All sections were in the first instance examined by one of us without previous knowledge of the clinical findings.

\section{Follow-up}

All the patients have since been followed up for $a$ 응. minimum period of 9 months, the majority for over a? year.

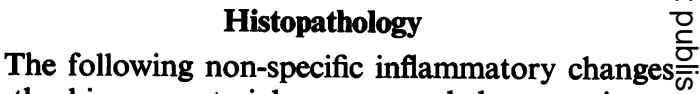
in the biopsy material were regarded as consistent $\frac{\text { }}{\widetilde{ }}$ with a diagnosis of rheumatoid arthritis.

(1) Synovial hyperplasia.

(2) Proliferation of superficial synovial cells. (synoviocytes).

(3) Increased vascularity and oedema of the subintimal layer.

(4) Marked lymphocytic and/or plasma cell in filtration of the subintima, either diffuse or with ${ }_{\omega}^{\bullet}$ a tendency to form focal aggregations in swollen i synovial villi.

These changes were seen in four of the other biopsies? (Fig. 1, and Fig. 2, overleaf), but it should be empha-

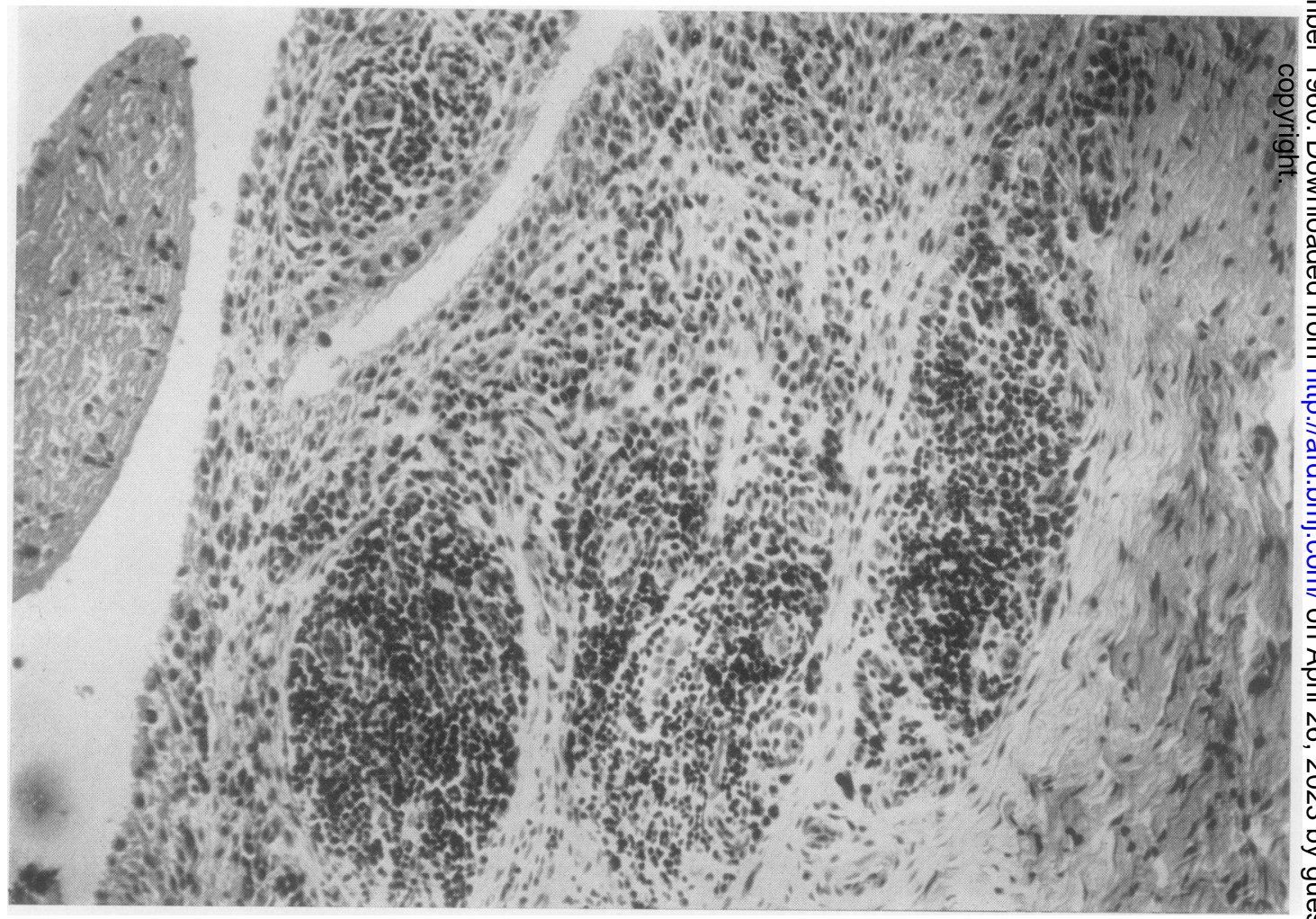

Fig. 1.-Case 7. Metacarpophalangeal joint capsule showing swollen synovium heavily infiltrated with lymphocytes and plasma cells. Surface fibrinous exudate on left. Haematoxylin and eosin. $\times 160$. 


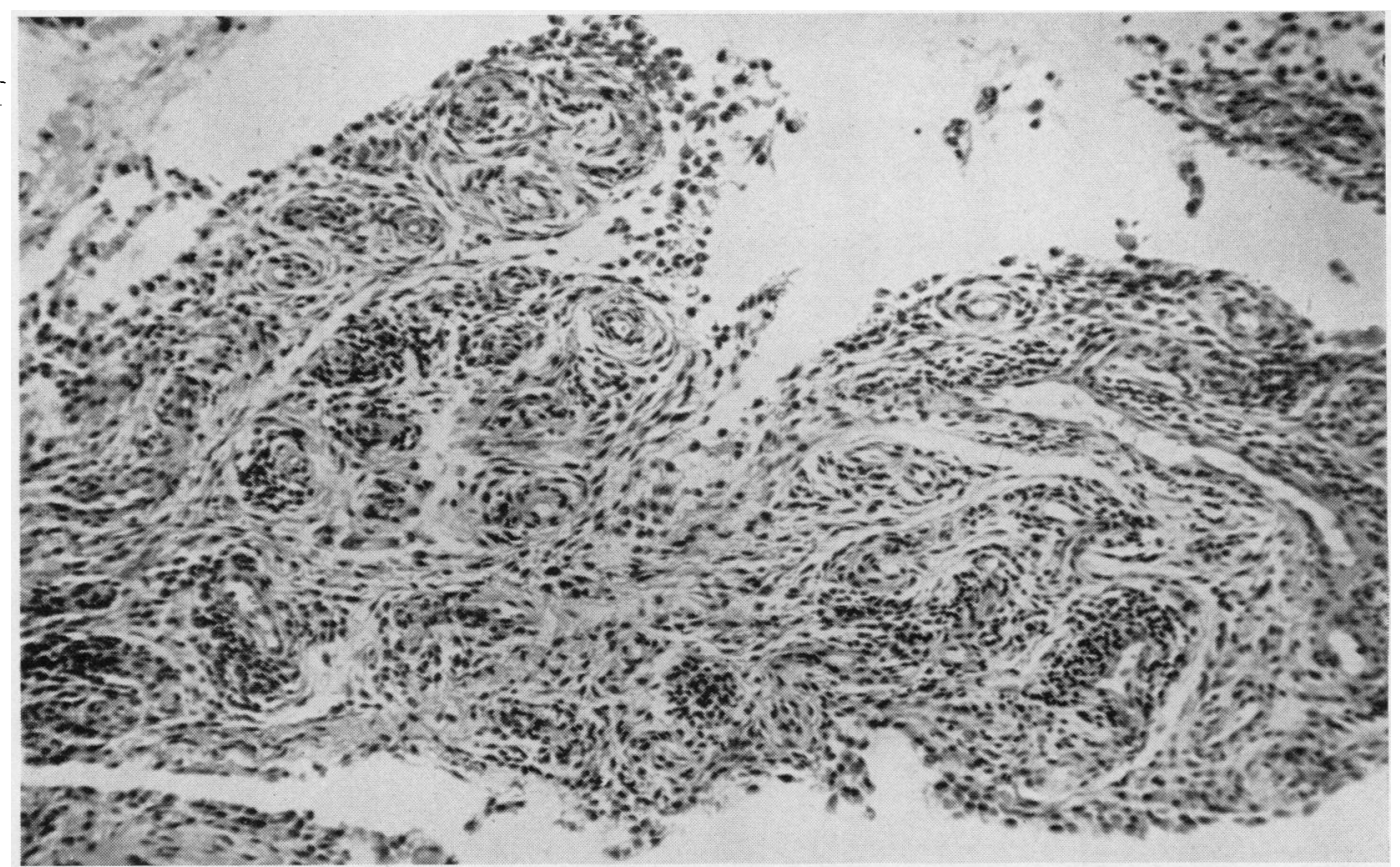

Fig. 2.-Case 5. Thickened synovial villus showing patchy synoviocytic hyperplasia with increased vascularization and moderate lymphocytic and plasma cell infiltration of the sub-intima. Perivascular cellular cuffing is present. Haematoxylin and eosin. $\times 93$.

sized that the flamboyant massive cellular infiltration with profusion of lymphoid follicles seen in biopsies of larger joints in some cases of rheumatoid disease was never observed in the present series. In three of these cases fibrinous exudate was deposited on the synovial surface. All four biopsies showed moderate numbers of mast cells in the subintimal, cellular infiltrate. The mast cells were present round the small blood vessels and in the loose areolar tissue. In some areas these cells had infiltrated the overlying synoviocytic layer.

Small granulomatous foci with fibrinoid deposition were seen in the fibrous capsule of the joint in two other biopsies (Fig. 3, overleaf). In the affected areas the normal dense fibrous tissue of the stratum fibrosum was replaced by highly vascular inflammatory tissue, containing numerous newly-formed capillaries and variable numbers of lymphocytes, plasma cells, histiocytes, polymorphs, and fibroblasts. Strongly fuchsinophilic fibrinoid material was deposited adjacent to the microgranulomata, and in both the vascular and necrotic foci the normal collagen structure had been disrupted or obliterated. We regarded the presence of these capsular lesions as compatible with the diagnosis of rheumatoid disease, although the foci lacked the structure of a typical rheumatoid nodule and the overlying stratum synoviale showed only a mild inflammatory reaction.

Eight of the remaining 24 biopsies showed definite evidence of a synovitis. The inflammatory reaction was insufficiently florid to justify a definite histological diagnosis of rheumatoid arthritis (Fig. 4, overleaf), but they all presented some of the abovementioned features.

One biopsy (Case 11) showed a copious fibrinocellular surface exudate, obliteration of the synovial layer, and an intense acute inflammatory reaction containing numerous polymorphs in the thickened highly vascular subintima (Fig. 5, overleaf). No bacteria were seen and the picture was compatible with an acute synovitis. Subsequent follow-up suggested that the lesion was an acute form of early rheumatoid synovitis.

The other fourteen biopsies showed no evidence of an active synovitis. Distinction between normality or minor degrees of synovial degeneration and fibrosis was not always clear.

Thirteen of the 24 biopsies showed partial transformation of the synoviocytic and subintimal layers into hypocellular, avascular tissue that in some sections closely resembled fibrocartilage (Fig. 6 , overleaf). Various transitional forms between typical synovial tissue and typical cartilage were seen, 


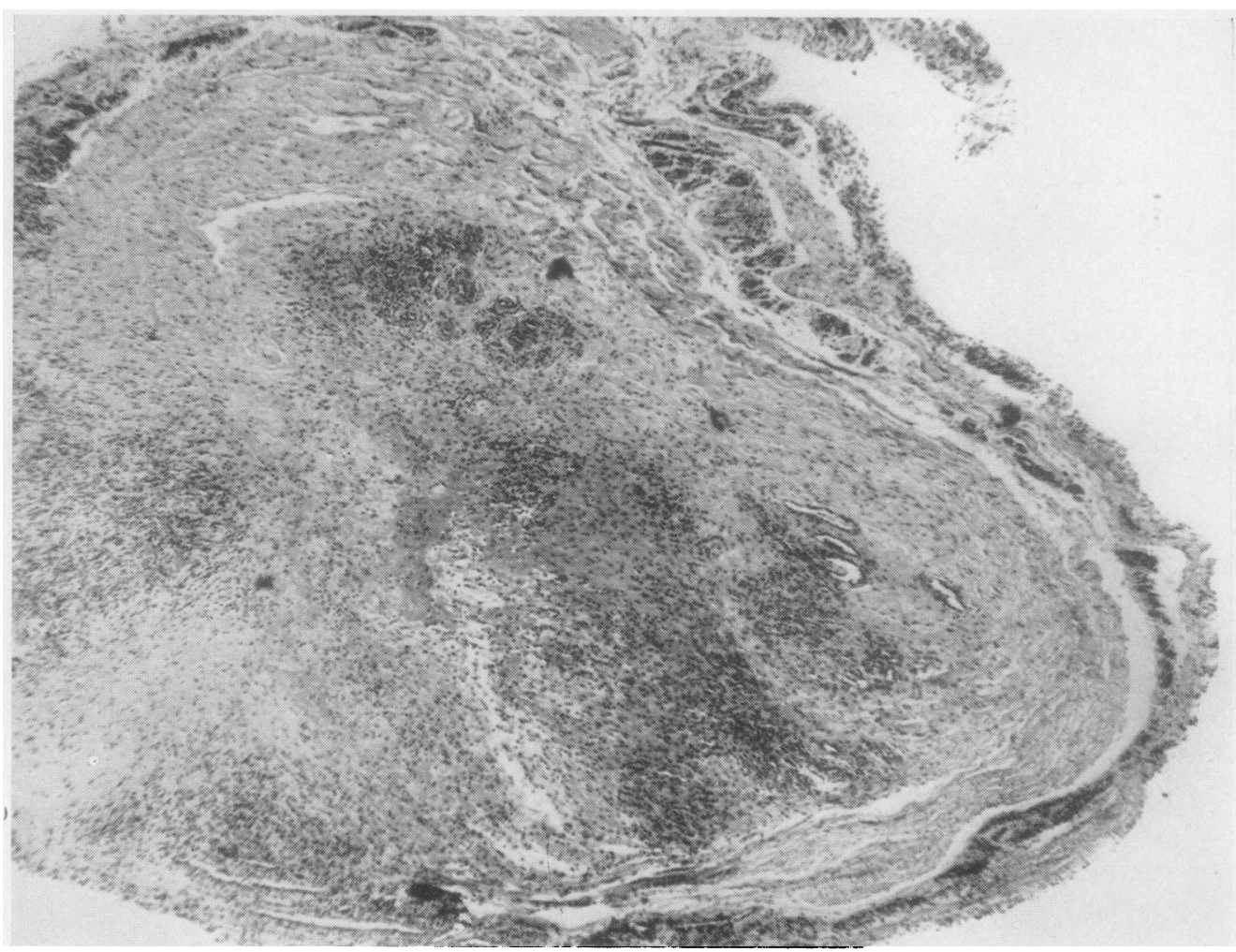

Fig. 3.-Case 6. Darkly stained microgranulomata in fibrous capsule of metacarpophalangeal joint. Minimal cellular reaction in stratum synoviale on right.

Haematoxylin and eosin. $\times 37$.

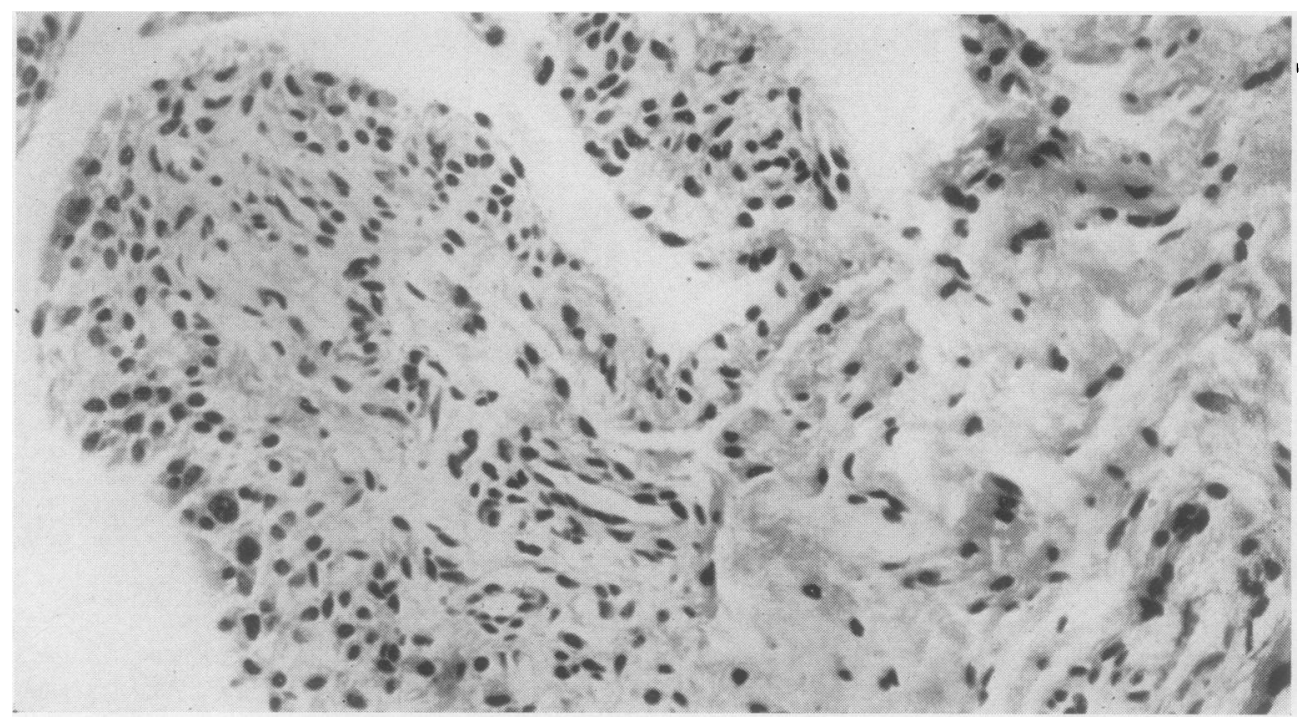

Fig. 4.-Case 12. Mild synovial hyperplasia with light chronic non-specific inflammatory reaction in sub-intima. Haematoxylin and eosin. $\times 206$. 


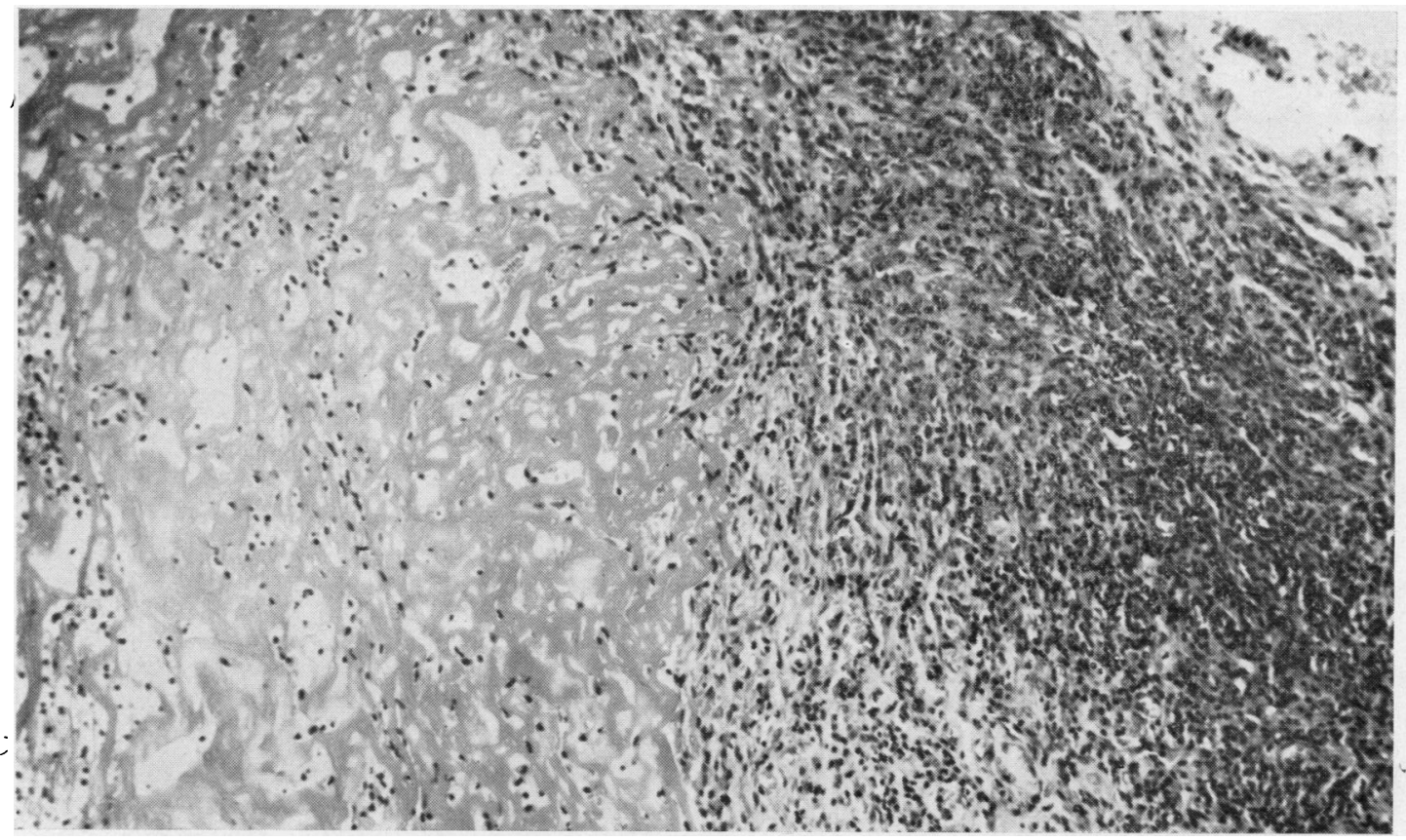

Fig. 5.-Case 11. Acute inflammatory changes in stratum synoviale with fibrino-cellular surface exudate on left. Haematoxylin and eosin. $\times 93$.

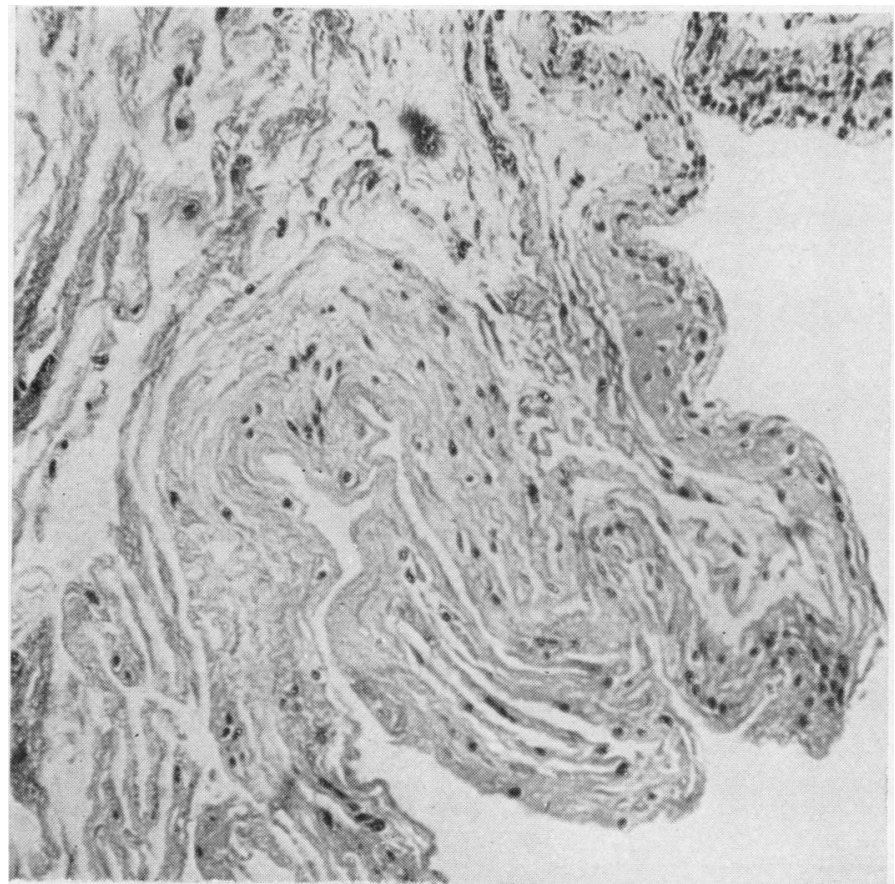

Fig. 6.-Case 22. Synovium denuded of surface cells and showing devascularization of subsynovial tissue with chondroid metaplasia.

Haematoxylin and eosin. $\times 80$. and in some specimens this chondroid metaplasia was quite striking.

One remaining biopsy consisted of a small fragment of fibrous tissue devoid of synovia and was considered inadequate for histological diagnosis.

In several specimens the small arteries showed medial hypertrophy and subintimal thickening, but fibrinoid necrosis of the arterial wall was observed in one case only. Subintimal pericapillary fibrosis was a common finding.

The biopsies were very small in several cases which showed little or no inflammatory activity. This was regarded initially as an error of technique, but it was later appreciated that such synovial specimens were either normal or atrophic in contrast to the relatively abundant tissue available for sectioning from cases with active inflammatory lesions.

None of the biopsies showed histological evidence of tuberculosis or gout. 
The thirty cases were classified on histological evidence as follows (Table):

Group 1: Six showing changes consistent with a diagnosis of rheumatoid arthritis (Cases 2, $4,5,6,7,13$ ) and one (Group 1a) with acute synovitis (Case 11).

Group 2: Eight showing evidence of chronic synovitis but with changes too slight to justify a definite diagnosis of rheumatoid arthritis (Cases 1, 3, 8, 9, 10, 12, 14, 17).

Group 3: Fourteen showing minimal inflammatory changes, fibrosis, and degeneration, or with normal tissue (Cases 15, 16, 18, 19, 20, 21, $22,23,24,25,26,27,28,29)$.

Group 4: One in which the tissue obtained at biopsy was insufficient for diagnosis (Case 30 ).

\section{Clinico-Pathological Correlation}

It was pointed out by Cruickshank (1952), in his study of consecutive biopsies from larger joints, that a single specimen might not show the full inflammatory picture and that biopsies from different areas of the same joint often showed widely differing pathological states. We were therefore surprised to find that the pathological picture from a single biopsy of a small joint could be correlated with the clinical diagnosis.

As a result of the follow-up of our cases, a clinical diagnosis has been reached in all but three. When the diagnosis is compared with the histological findings it appears that evidence of some inflammatory change in the synovia corresponds with the rheumatoid arthritis group, whereas absence of inflammatory change or normal synovia is found in the group with osteo-arthritis.

Although no case showed the classical foci of rheumatoid arthritis described by Allison and Ghormley (1931), there was sufficient evidence in seven of the biopsy specimens to justify a histological diagnosis of rheumatoid arthritis. In this series it appears that the presence of a milder degree of synovitis was also associated with rheumatoid arthritis, but, as might be expected, the degree of histological change was not related to the severity of the clinical picture. Of the three cases of typical early acute rheumatoid arthritis used as "controls", one showed marked inflammatory changes in the synovia, and the other two only

CLINICAL AND PATHOLOGICAL FINDING

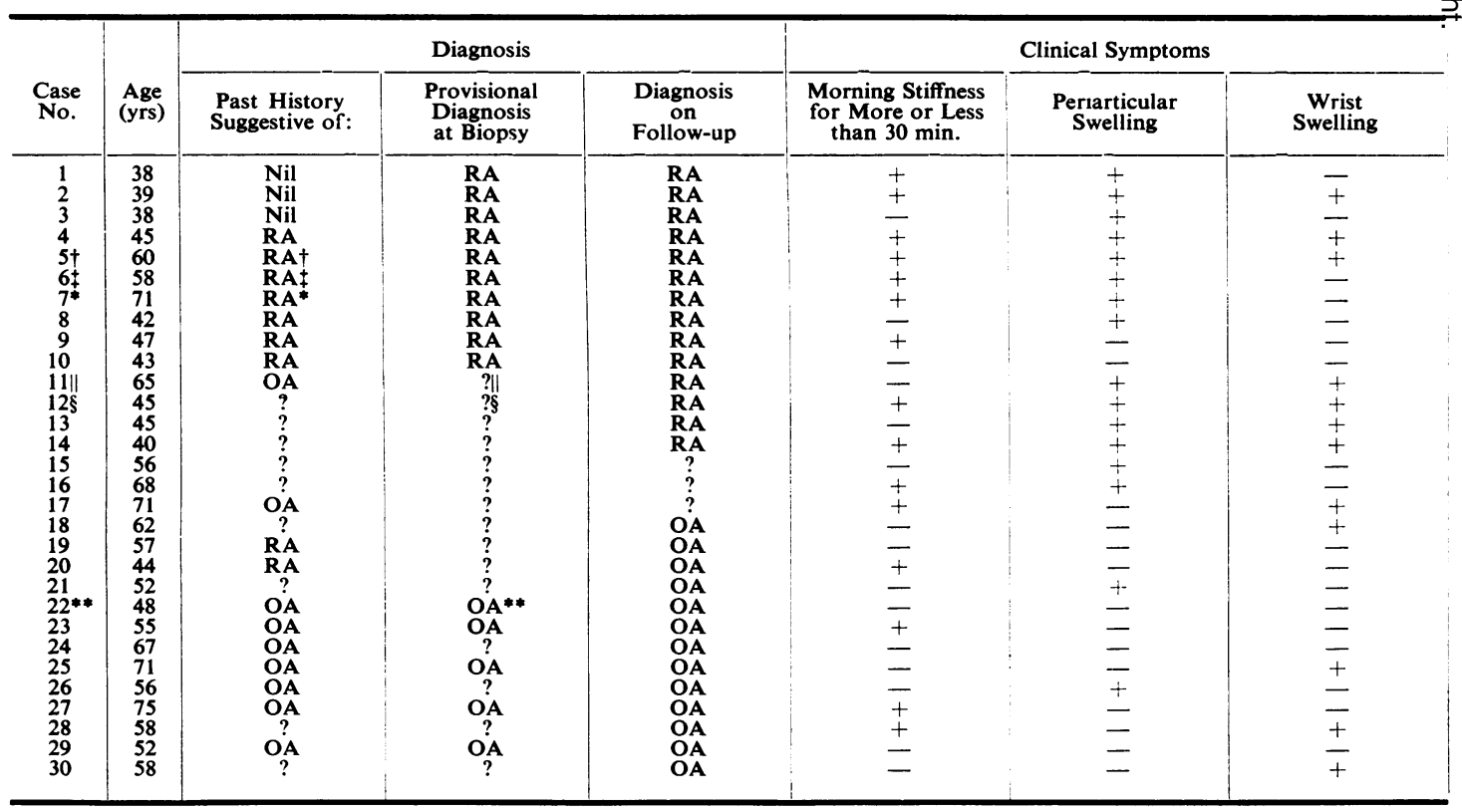

RA = Rheumatoid Arthritis

OA $=$ Osteo-arthritis

* Fig. 1. † Fig. $2 . \quad \ddagger$ Fig. 3. § Fig. 4. \| Fig. 5. ** Fig. 6. 
mild synovitis. On the whole, however, there was a tendency for cases in which a diagnosis of rheumatoid arthritis was considered most likely at the time of biopsy to show a more florid histological picture.

Moderate numbers of mast cells in the inflammatory cellular infiltrate in rheumatoid synovitis has rarely been recorded; Kulka and others (1955) briefly mentioned their presence in one of a series of synovial biopsies from knee joints in cases of early rheumatoid arthritis. However, it is unlikely that this observation has any special diagnostic significance.

Previous work on the pathological changes in the joints in osteo-arthritis has stressed the relative absence of inflammatory changes in synovial tissue (Collins, 1949). Nevertheless, we were surprised to find normal or even atrophic synovia in joints which were clinically swollen and painful. However, the absence of inflammatory changes appeared to be of considerable diagnostic significance, since none of these patients has developed a clinical picture of rheumatoid disease during follow-up.

A fairly high proportion of biopsies showing some degree of chondroid transformation of the synovial layer was noted. It is possible that such metaplasia is associated with a degenerative or atrophic process occurring in the mesenchymal elements of the synovia, although, according to Maximow and Bloom (1957), small amounts of cartilage and all transitions between cartilage cells and joint or synovial cells can be found occasionally in normal diarthrodial joints. Much has been written about the arterial changes in rheumatoid arthritis (Cruickshank, 1954; Ball, 1954; Kulka and others, 1955; Clark, Kulka, and Bauer, 1957; Bywaters, 1957; Kellgren and Ball, 1959), but there is no great measure of agreement about their nature or significance. In our patients there were changes in the small arteries (medial hypertrophy, subintimal thickening) and in the capillaries (pericapillary fibrosis) in a number of cases, but, although they were rather more common in the group with active synovitis (twelve out of fifteen cases), such changes were seen together with normal or quiescent synovia in five out of fourteen cases.

In some sections, concentric intimal thickening of the arterioles was seen. These changes were not unlike those described by Whiteley and Wilson (1952); Wade and Ball (1957); Bywaters (1957); and

BLE

IN THIRTY PATIENTS SUBMITTED TO BIOPSY

\begin{tabular}{|c|c|c|c|c|c|}
\hline \multicolumn{3}{|c|}{ Radiology } & \multicolumn{2}{|c|}{ Laboratory Tests } & \multirow[b]{2}{*}{$\begin{array}{l}\text { Biopsy } \\
\text { Group }\end{array}$} \\
\hline Porosis & Erosions & Sclerosis & $\begin{array}{c}\text { Rose-Waaler } \\
\text { Test }\end{array}$ & $\begin{array}{l}\text { Highest Erythrocyte } \\
\text { Sedimentation Rate } \\
\text { (mm./hr; Westergren) }\end{array}$ & \\
\hline+ & $\bar{z}$ & $=$ & + & 12 & 2 \\
\hline $\begin{array}{l}+ \\
+\end{array}$ & 二 & 二 & $二_{+}^{+}$ & $\begin{array}{l}57 \\
45\end{array}$ & $\begin{array}{l}1 \\
2\end{array}$ \\
\hline $\begin{array}{l}+ \\
+\end{array}$ & + & \pm & \pm & 25 & 1 \\
\hline+ & $\frac{1}{+}$ & + & -+ & 29 & 1 \\
\hline$\frac{t}{t}$ & $\underline{-}$ & $\begin{array}{l}+ \\
+ \\
+\end{array}$ & $\bar{t}$ & 23 & $\frac{1}{2}$ \\
\hline+ & 二 & + & \pm & 29 & $\frac{2}{2}$ \\
\hline \pm & 二 & + & -+ & 37 & $1 a$ \\
\hline- & - & + & 二 & 23 & 1 \\
\hline 二 & 二 & $\bar{t}$ & 三 & $\begin{array}{l}7 \\
10\end{array}$ & 3 \\
\hline 二 & 二 & $\stackrel{+}{+}$ & 二 & 7 & 3 \\
\hline 二 & 二 & + & $=$ & 20 & 3 \\
\hline 二 & 二 & \pm & + & $\begin{array}{l}20 \\
15\end{array}$ & 3 \\
\hline 二 & 二 & + & 二 & 6 & 3 \\
\hline 二 & - & + & - & 10 & 3 \\
\hline I & - & + & - & 40 & 3 \\
\hline \pm & 二 & + & 二 & 12 & 3 \\
\hline 二 & 二 & \pm & $=$ & $\begin{array}{l}38 \\
10\end{array}$ & 3 \\
\hline - & - & . & - & 26 & 4 \\
\hline
\end{tabular}


Kellgren and Ball (1959), to which the name fibroelastosis has been given. But it should be stated that the biopsies in our series were not processed or examined with the particular object of studying vascular lesions.

When we compared the clinical findings at the time of biopsy with the histological picture in the light of the final diagnosis, certain clinical features appeared to be particularly important in the diagnosis of rheumatoid arthritis. Morning stiffness for more than 30 minutes was present in nine of fourteen cases in the rheumatoid group, but in only four of the thirteen cases in the osteo-arthritic group. Severe periarticular swelling with transmetacarpal tenderness was also found to vary in the two groups in the same proportions.

Although a history suggestive of rheumatoid arthritis in the past was helpful in the majority of cases, in two cases it was misleading. Both patients had a previous history of rheumatoid disease with a positive Rose-Waaler test, one having received steroid therapy. At the time of biopsy the Rose-Waaler test was negative and the clinical diagnosis was in doubt. Biopsy specimens from these patients showed inactive synovial tissue, and neither exhibited any further clinical evidence of rheumatoid arthritis.

\section{Discussion}

Although there have been striking advances in the diagnosis and treatment of rheumatoid arthritis in the last 20 years, the exact definition in many early cases remains obscure. The introduction of serological tests has assisted the diagnosis of rheumatoid disease, but in osteo-arthritis there is very little laboratory aid. Serological tests, however, do not necessarily differentiate the early stages of illness, when the overlap of signs and symptoms makes accurate clinical diagnosis impossible.

In women over 40 years of age, degenerative changes in the joints of the hands are frequently present, together with Heberden's nodes. While these are suggestive of osteo-arthritis, their presence does not exclude rheumatoid disease, nor does a past history of rheumatoid arthritis prevent the onset of primary generalized osteo-arthritis. Systemic or constitutional symptoms are not marked in primary generalized osteo-arthritis, nor often in the early stages of rheumatoid arthritis, but menopausal symptoms occurring in either group may add to the confusion.

Cecil and Archer $(1925,1926)$ classified 145 of 182 cases of degenerative arthritis as "arthritis of the menopause". Though this term proved to be illchosen, in so far as later work failed to show a definite correlation between endocrine changes and the development of osteo-arthritis, it focused attention on the great problem of arthritis occurring initially in middle-aged women.

Although, in the majority of cases, a clinical diagnosis can be made after a period of observation, the importance of early accurate diagnosis lies in the different treatment and prognosis of the two conditions. Duthie, Thompson, Weir, and Fletcher (1955) have shown that patients with rheumatoid arthritis do better if they receive intensive treatment, preferably in hospital, in the early stages of the disease. Early treatment leads to a quicker return to normal life with a smaller chance of relapse and permanent crippling. On the other hand, Kellgren and Moore (1952) found that, in their cases of osteo-arthritis, although there was a certain amount of deformity, permanent crippling very seldom occurred and the disease tended to run a selflimiting and benign course.

The study of a relatively small number of cases has shown that open biopsy is a reasonably safe procedure, and that sufficient material can usually be obtained for histological study. There have been no permanent complications, although transient attacks of pain and stiffness in the biopsied joint occurred in a number of patients. The patiento whose specimen showed acute synovitis developed an effusion into the joint 4 months after biopsyo when there was a general exacerbation of the? rheumatoid process, but with intra-articular hydrocortisone therapy the effusion resolved without further complications.

The majority of patients in whom the synovial tissue showed evidence of inflammatory changes, though these were often mild, subsequently developed the clinical features of rheumatoid arthritis. We therefore felt that it would be justifiable to treat these patients as cases of rheumatoid arthritis on the basis of the histological findings. On the other hand, the patients without evidence of synovial inflammation appeared to be suffering from primary generalized osteo-arthritis; the pain and swelling of the joint being probably due to soft tissue swelling, associated with mucoid degeneration of the connective tissue. This change is thought to precede the new bone formation in Heberden's nodes (Collins, 1949).

Six cases in the rheumatoid group had a persistently negative Rose-Waaler test; in those in whom the clinical course was benign, the differential diagnosis between an evanescent attack of rheumatoid arthritis and acute osteo-arthritis could only have been made at an earlier stage on histological evidence. 


\section{Conclusion}

Within the limitations of a small series and a relatively short period of follow-up, biopsy of the second metacarpophalangeal joint has been found useful in the differential diagnosis of the painful swollen hand, where this could not be made on clinical, serological, and radiological evidence.

Although there were no complications, biopsy is not advocated as a routine measure, but should be considered in the following circumstances:

(1) When a rheumatoid process may be superimposed on degenerative changes.

(2) When the pattern of joint involvement is not characteristic.

(3) When serological tests and $x$ rays are unhelpful.

(4) When the line of treatment is doubtful.

From the results of this series two main groups of patients emerge:

(a) That in which the biopsy specimen shows evidence of inflammatory changes. Clinically the majority of these patients showed evidence of rheumatoid arthritis, either at the time of biopsy or on follow-up. It is suggested that all such cases should be treated as cases of rheumatoid arthritis.

(b) That in which the biopsy specimen showed normal or inactive synovial tissue. None of these patients developed rheumatoid arthritis on follow-up, and they were thought to be suffering from primary generalized osteoarthritis, requiring supportive therapy and reassurance.

Clinical features which correlated well with the pathological findings were morning stiffness for more than 30 minutes and marked periarticular swelling. It was not possible to distinguish histologically between serologically positive and negative cases of rheumatoid arthritis. Two patients with a past history of serologically positive rheumatoid disease showed quiescent synovia, indistinguishable from that seen in osteo-arthritis.

\section{Summary}

Thirty women presenting with pain and swelling of the hands submitted to biopsy of the second metacarpophalangeal joint of one hand.

The problems of differential diagnosis between rheumatoid arthritis and osteo-arthritis in patients over $\mathbf{4 0}$ years of age are discussed. The technique of biopsy of the second metacarpophalangeal joint is described and the results correlated with the clinical features both at the time of biopsy and at follow-up.

Histologically, the specimens were divided into two main groups: those showing inflammatory changes in the synovia and those with normal or atrophic tissue. Patients with rheumatoid arthritis showed inflammatory changes in the synovial tissue, whereas there was no evidence of inflammation in the synovia of osteo-arthritic patients.

Follow-up for over one year showed that none of the patients with uninflamed synovia subsequently developed rheumatoid arthritis.

In view of these findings it is suggested that biopsy of the second metacarpophalangeal joint in certain circumstances could be a valuable guide to early diagnosis.

Our thanks are due to Dr. A. T. Richardson for his valuable advice and encouragement, and permission to use his cases, and to Prof. K. R. Hill for kind permission to use his laboratory facilities. We are also indebted to Mr. J. A. Turner for helping to devise the biopsy technique, to Mr. R. R. Phillips for the photomicroscopy, and to Mr. G. Humblestone for technical assistance.

\section{REFERENCES}

Allison, N. and Ghormley, R. K. (1931). "Diagnosis in Join Allison, N. and Ghormley, R. K. (1931), "Diag

Ball, J. (1954). Ann. rheum. Dis., 13, 277.

Bywaters, E. G. L. (1957). Ibid., 16, 84.

Cecil, R L. and Archer, B. H. (1925). J. Amer. med. Ass., 84, 75. C, (1926). Ibid.., 87, 741.

Clark, W. S., Kulka, J. P., and Bauer, W. (1957). Amer. J. Med., $22,580$.

Collins, D. H. (1949). "The Pathology of Articular and Spinal Diseases." Arnold, London.

Cruickshank, B. (1952). Ann. rheum. Dis., 11, 137.

(1954), Ibid., 13, 136.

Duthie, J. J. R., Thompson, M., Weir, M. M., and Fletcher, W. B. (1955). Ibid., 14, 133.

Hargreaves, E. R. (1958). Ibid., 17, 61.

Kellgren, J. H. and Ball, J. (1959). Brit. med. J., 1, 523.

Kellgren, Moore, R. (1952). Ibid., 1, 181 .

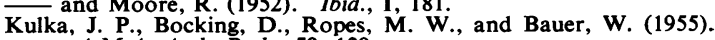
A.M.A. Arch. Path., 59, 129.

Maximow, A. A. and Bloom, W. (1957). "Textbook of Histology" 7th ed. Saunders, Philadelphia.

Wade, G. and Ball, J. (1957). Quart. J. Med., 26, 83

Whiteley, H. J. and Wilson, G. M. (1952). J. Path. Bact., 64, 705

Diagnostic précoce de l'arthrite de la main.-Etude clinique et pathologique des mains douloureuses et tuméfiées des femmes âgées de plus de 40 ans

RÉSUMÉ

On procéda, chez trente femmes aux mains tuméfiées et douloureuses, à des biopsies de la deuxième articulation métacarpo-phalangienne d'une main.

On discute le problème de diagnostic différentiel entre l'arthrite rhumatismale et l'ostéoarthrite chez des femmes âgées de plus de 40 ans. On décrit la technique de la biopsie de la deuxième articulation métacarpo-phalangienne et on met en correlation les résultats avec le tableau clinique au temps de la biopsie et pendant une période d'observation subséquente.

Histologiquement, on divise les prélèvements en deux groupes: l'un portant des signes d'inflammation synoviale et l'autre caractérisé par des tissus normaux ou atrophiques. Les malades atteints d'arthrite rhumatismale accusent des altérations inflammatoires de la membrane synoviale, tandis que des signes d'une telle inflammation sont absents dans l'ostéoarthrite.

L'observation pendant plus d'un an montre que les malades à la membrane synoviale non-inflammée ne sont pas frappés par l'arthrite rhumatismale. 
En vue de ces résultats on suggère qu'une biopsie de la deuxième articulation métacarpo-phalangienne, en certaines circonstances, peut être un guide utile pour le diagnostic précoce.

Diagnóstico precoz de la artritis de la mano.-Estudio clínico-patológico de manos hinchadas y dolorosas en mujeres de edad superior a 40 años

\section{Sumario}

Treinta mujeres con dolor e hinchazón de las manos fueron sometidas a biopsia de la segunda articulación metacarpo-falangiana de una mano.

Se discuten los problemas de diagnóstico diferencial entre artritis reumatoide $y$ ósteo-artritis en enfermos de más de 40 años de edad. Se describe la técnica de la biopsia de la segunda articulación metacarpo-falangiana y los resultados se relacionan con el cuadro clínico en el momento de la biopsia y durante el período posterior de observación.

Histológicamente, el material se divide en dos grupos $\bar{n}$. uno con cambios inflamatorios de la sinovia y el otro: con tejidos normales o atróficos. Los enfermos conss artritis reumatoide presentan alteraciones inflamatorias de la membrana sinovial, mientras que no existe evidencia de inflamación en la sinovia de los enfermosos

La observación continuada de los enfermos por más历 de un año demuestra que ninguno de aquellos que no presentaron inflamación sinovial desarrolla posterior-w mente artritis reumatoide.

En vista de los resultados se sugiere que la biopsia. de la segunda articulación metacarpo-falangiana puedeser, en determinadas circunstancias, una guia de valorw en el diagnóstico precoz. 